\title{
Originals
}

\section{Prolonged hyperglycaemia during infusion of glucose and somatostatin impairs pancreatic A- and B-cell responses to decrements in plasma glucose in normal man: evidence for induction of altered sensitivity to glucose}

\author{
G. Dimitriadis ${ }^{1}$, P. Cryer ${ }^{2}$ and J. Gerich ${ }^{1}$ \\ ${ }^{1}$ Endocrine Research Unit, Departments of Medicine and Physiology, Mayo Medical School and Mayo Clinic, Rochester, Minnesota, and \\ ${ }^{2}$ Metabolism Division, Department of Internal Medicine, Washington University School of Medicine, St. Louis, Missouri, USA
}

\begin{abstract}
Summary. To determine the effects of prolonged hyperglycaemia on pancreatic islet A- and B-cell function, plasma glucose was clamped for $12 \mathrm{~h}$ at approximately 11 and $5 \mathrm{mmol} / 1$ in control experiments by infusing glucose and somatostatin along with replacement amounts of insulin, glucagon, and growth hormone in seven normal volunteers. Following restitution of euglycaemia for $1 \mathrm{~h}$ after prolonged hyperglycaemia, termination of the somatostatin-replacement hormone infusions resulted in a sustained decrease in plasma glucose to $3 \mathrm{mmol} / 1(p<0.01)$. Despite this, plasma glucagon did not increase above values observed in control experiments in which plasma glucose did not decrease; moreover, there was a persistent increase in insulin secretion nearly threefold above that
\end{abstract}

observed in control experiments $(p<0.01)$. Plasma growth hormone, cortisol and adrenaline responses were appropriate. This failure of a decrement in plasma glucose to suppress insulin secretion and to stimulate glucagon secretion was not observed when comparable hypoglycaemia was induced by exogenous insulin after a prolonged euglycaemic clamp. Our results indicate that hyperglycaemia can induce altered sensitivity of pancreatic $A$ and $B$ cells to glucose and suggest that abnormal A- and B-cell responses to glucose in diabetes mellitus may not represent a wholly intrinsic defect.

Key words: A cell, B cell, insulin, glucagon.
In human diabetes mellitus both the stimulation of insulin secretion glucagon secretion by hyperglycaemia are impaired [1, 2]. However secretion of these hormones stimulated by agents other than glucose is frequently normal or increased [3-8]. Furthermore, although glucagon secretion is not suppressed appropriately by hyperglycaemia $[3,9,10]$, it can be suppressed by increases in plasma non-esterified fatty acids [9]. This insensitivity of diabetic pancreatic $A$ and $B$ cells to glucose has been attributed to a glucoreceptor defect $[2,4$, $9,10-12]$. However, whether such a defect represents an intrinsic abnormality or merely the consequence of prolonged insulin deficiency or hyperglycaemia is unclear. Since prolonged hyperglycaemia down-regulates insulin receptors and leads to insensitivity to insulin [13], the present studies were undertaken to test the hypothesis that prolonged hyperglycaemia might induce A- and Bcell insensitivity to glucose.

\section{Subjects and materials}

\section{Subjects}

Informed written consent was obtained from ten normal volunteers (four men, six women aged $27 \pm 1$ years) who were non-obese (body mass index $24 \pm 2 \mathrm{~kg} / \mathrm{m}^{2}$ ) and who had no family history of diabetes. A total of 20 studies were conducted at the Mayo Clinic General Clinical Research Unit at 1-3 week intervals.

\section{Study design}

On each occasion, somatostatin $(250 \mu \mathrm{g} / \mathrm{h}$, courtesy of Drs. N. Ling and R.Guillemin, Salk Institute, La Jolla, California) was infused overnight for a total of $12 \mathrm{~h}$ beginning at approximately $08.00 \mathrm{~h}$ together with replacement infusions of insulin $\left(0.2 \mathrm{mU} \cdot \mathrm{kg}^{-1} \cdot \mathrm{min}^{-1}\right.$,

Table 1. Plasma glucose, insulin, glucagon, growth hormone, cortisol, and adrenaline concentrations during 12 -h hyperglycaemic and euglycaemic clamps

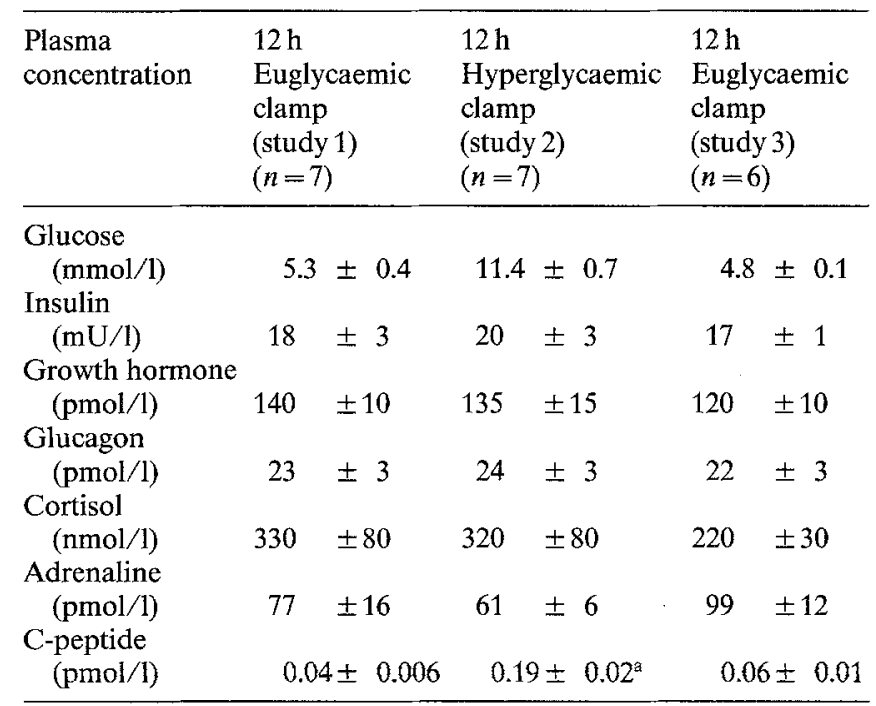

Results expressed as mean \pm SEM.

${ }^{a} p<0.05$ study 1 and 2 


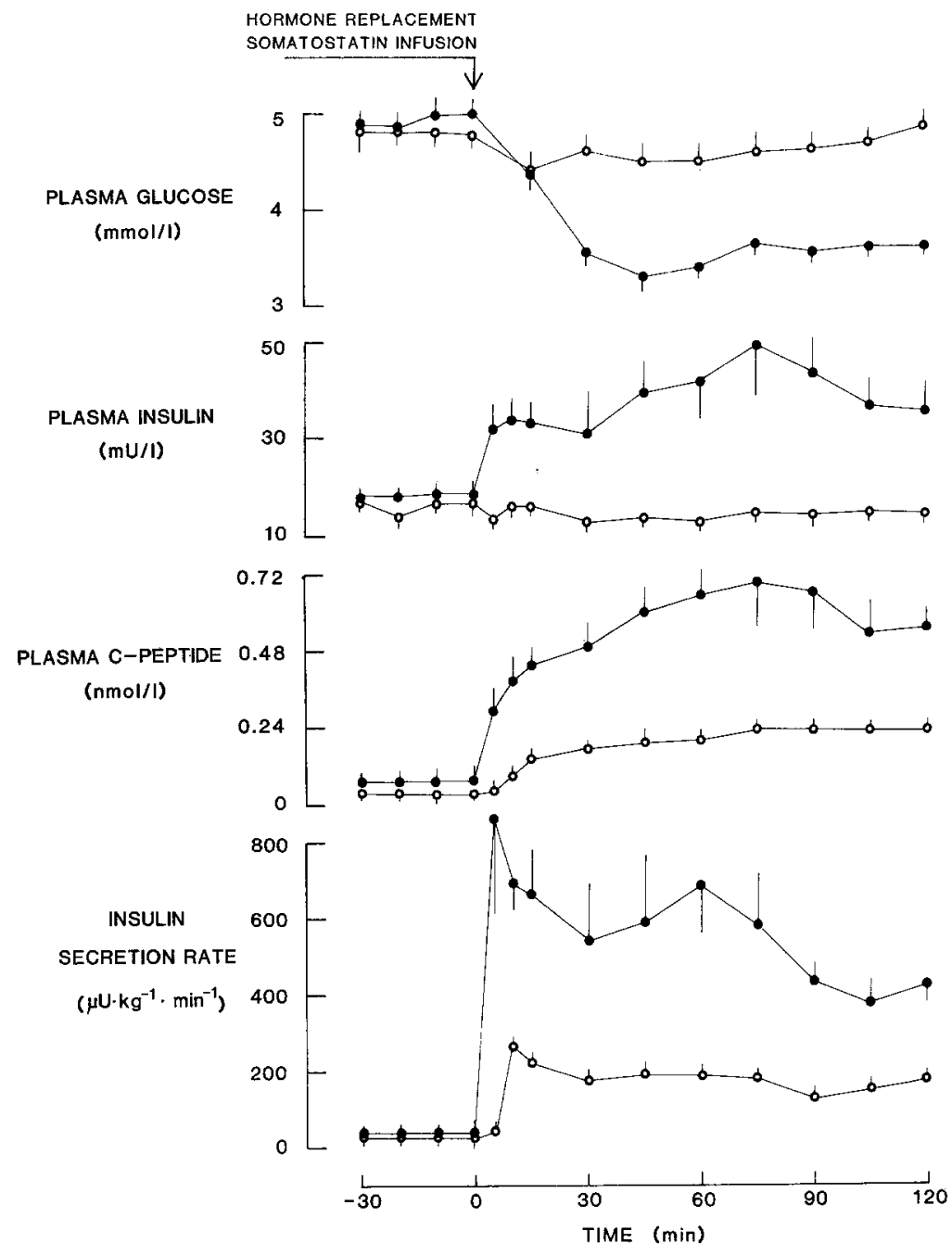

Fig. 1. Plasma glucose, insulin, and C-peptide concentrations and insulin secretion rates in seven normal volunteers following cessation of somatostatin and replacement hormone infusions after 12-h euglycaemic $(\mathrm{O}-\mathrm{O})$ and hyperglycaemic clamps (mean \pm SEM). The $\downarrow$ indicates the time at which the somatostatin and replacement hormone infusions were stopped crystalline porcine, Eli Lilly, Indianapolis, Indiana), glucagon $\left(0.5 \mathrm{ng} \cdot \mathrm{kg}^{-1} \cdot \mathrm{min}^{-1}\right.$, Eli Lilly), and growth hormone $\left(10 \mathrm{ng} \cdot \mathrm{kg}^{-1}\right.$. $\mathrm{min}^{-1}$, National Pituitary Agency, Baltimore, Maryland) to maintain arterialized-venous plasma concentrations of these hormones at basal values. During this period, a closed-loop glucose infusion device (Biostator, Life Science Instruments, Elkhart, Indiana) was used to clamp plasma glucose [14], on one occasion at euglycaemic levels $(4.8-5.3 \mathrm{mmol} / \mathrm{l})$ (study 1 ) and on another occasion at hyperglycaemic levels $(11.1 \mathrm{mmol} / \mathrm{l})$ (study 2). During the final hour of the $12-\mathrm{h}$ period of study 2, plasma glucose was clamped at euglycaemic levels to ensure that baseline plasma glucose concentrations would be comparable in both experiments. The order of the studies was random. At the end of the 12-h period, somatostatin, hormone replacement and Biostator glucose infusions were stopped, and blood samples were obtained at 5-15 min intervals over $2 \mathrm{~h}$ for determination of plasma glucose, insulin, C-peptide, glucagon, growth hormone, cortisol and adrenaline.

Because of the development of hyperglycaemia after the prolonged hyperglycaemia clamp, an additional experiment (study 3 ) was carried out to assess the appropriateness of islet A- and B-cell responses during hypoglycaemia preceded by euglycaemia: identical hypoglycaemia was induced in six subjects (three of whom participated in both studies 1 and 2 and three additional volunteers, two men and one women - aged $23 \pm 2$ years, body mass index $24 \pm 2 \mathrm{~kg} / \mathrm{m}^{2}$ ) after their plasma glucose had been clamped at euglycaemic levels for $12 \mathrm{~h}$ as described above. Following cessation of the somatostatin, hormone replacement and Biostator glucose infusions, a continuous $2-h$ infusion of insulin $\left(0.5 \mathrm{mU} \cdot \mathrm{kg}^{-1} \cdot \mathrm{min}^{-1}\right)$ was started with a Harvard pump (Harvard Apparatus, Millis, Massachusetts) to approximate the circulating insulin concentration observed in study 2. Plasma glucose was clamped at hypoglycaemic levels similar to the mean values observed in study 2 by means of a glucose infusion through a separate Harvard pump [14].

\section{Laboratory methods}

Plasma glucose (Yellow Springs Instruments Glucose Analyzer, Yellow Springs, Ohio), C-peptide [15], insulin [16], glucagon [17], growth hormone [18], cortisol [19], and adrenaline [20] concentrations were determined on arterialized-venous blood specimens [21] obtained at $5-15$-min intervals before and after cessation of the somatostatin hormone replacement infusions. Insulin secretion rates were calculated using the model of Eaton et al. [22] based on changes in circulating Cpeptide concentrations. During the 12 -h hyperglycaemic and euglycaemic clamp periods, plasma insulin, glucagon, adrenaline, cortisol, and growth hormone were determined at 3-h intervals.

\section{Statistical analysis}

All data are given as mean \pm SEM. Analysis of variance, two-tailed paired and, when appropriate, non-paired Student's t-test were used for statistical analysis.

\section{Results}

\section{Baseline plasma glucose and hormone concentrations}

Plasma glucose concentrations were maintained at $5.3 \pm 0.4 \mathrm{mmol} / 1$ during the $12-\mathrm{h}$ euglycaemic clamp period (study 1 ), at $11.4 \pm 0.7 \mathrm{mmol} / 1$ over the same inter- 


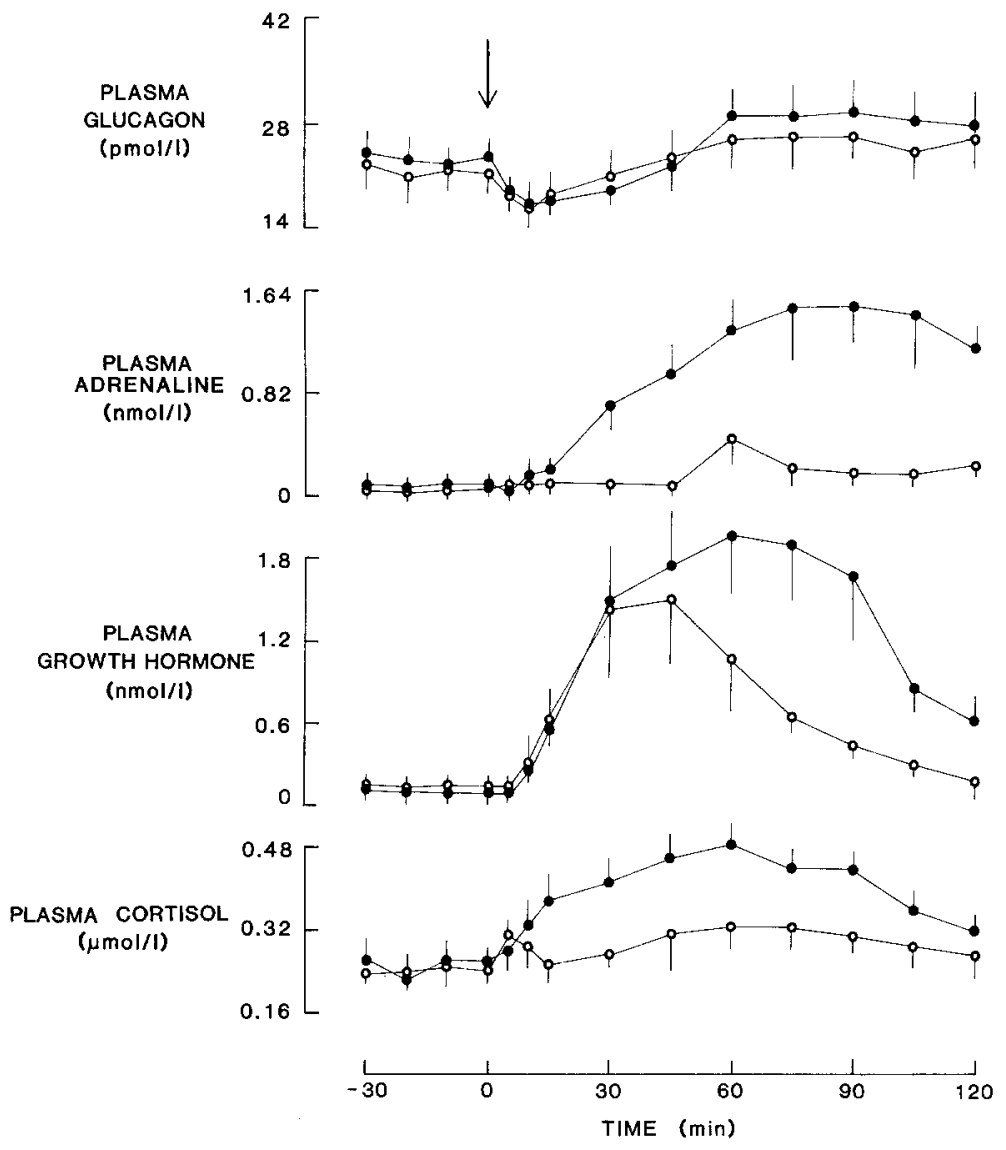

Fig. 2. Plasma glucagon, adrenaline, growth hormone, and cortisol concentrations in seven normal volunteers following cessation of somatostatin and replacement hormone infusions after $12-\mathrm{h}$ euglycaemic $\left(\mathrm{O}_{-} \mathrm{O}\right)$ and hyperglycaemic $(-$ ) clamps (mean \pm SEM). The $\downarrow$ indicates the time at which the somatostatin and replacement hormone infusions were stopped val during the hyperglycaemic clamp (study 2 ), and at $4.8 \pm 0.1 \mathrm{mmol} / \mathrm{l}$ during the $12-\mathrm{h}$ euglycaemic clamp in study 3 ; plasma insulin, glucagon, adrenaline, growth hormone, and cortisol concentrations during this period in each experiment were not significantly different from one another (Table 1). However in study 2, plasma Cpeptide $(0.19 \pm 0.02 \mathrm{pmol} / 1)$ was significantly greater than values observed in studies 1 and $3(0.04 \pm 0.003$ and $0.06 \pm 0.01 \mathrm{pmol} / 1$, respectively, $p<0.05$ ). After euglycaemia was re-established following the hyperglycaemic clamp (study 2), plasma glucose, insulin, glucagon, cortisol, growth hormone, and adrenaline concentrations were not significantly different from those during the same period in studies 1 and 3 , but plasma $C$ peptide levels $(0.08 \pm 0.01 \mathrm{mmol} / \mathrm{l})$ were significantly greater than those in studies 1 and $3(0.030 \pm 0.001$ and $0.040 \pm 0.003 \mathrm{mmol} / 1$, respectively, $p<0.05$ ).

\section{Effects of prolonged hyperglycemia on islet $A$ - and $B$-cell function}

In the control experiments, when the somatostatin-hormone replacement infusions were stopped following 12-h euglycaemia, plasma glucose decreased transiently (only at $15 \mathrm{~min}$ ) by about $0.4 \mathrm{mmol} / \mathrm{l}$; plasma insulin concentrations did not change significantly; the suppressed plasma C-peptide $(0.030 \pm 0.001 \mathrm{nmol} / 1)$ and insulin secretory rates $\left(19 \pm 1 \mu \mathrm{U} \cdot \mathrm{kg}^{-1} \cdot \mathrm{min}^{-1}\right)$ increased to levels $\left(0.24 \pm 0.02 \mathrm{nmol} / 1\right.$ and $170 \pm 32 \mu \mathrm{U} \cdot \mathrm{kg}^{-1}$. $\min ^{-1}$, respectively) observed in normal subjects in the post-absorptive state [23] (Fig.1). Plasma glucagon decreased transiently and returned to baseline values by $30 \mathrm{~min}$. In contrast, previously suppressed plasma growth hormone increased tenfold by $30 \mathrm{~min}$ and gradually returned to baseline values; there was no significant change in plasma adrenaline and cortisol (Fig. 2).

After prolonged hyperglycaemia, plasma glucose decreased to $3.3 \pm 0.1 \mathrm{mmol} / 1$ and remained nearly $2 \mathrm{mmol} / 1$ below values observed in control experiments for $2 \mathrm{~h}(p<0.01$; Fig. 1). Plasma insulin and C-peptide concentrations increased to $40 \mathrm{mU} / 1$ and $0.6 \mathrm{nmol} / 1$, respectively, and were both still more than twofold greater than respective values observed in the control experiments at $2 \mathrm{~h}(p<0.01)$. Insulin secretion rates increased more than 20 -fold to greater than $800 \mu \mathrm{U} \cdot \mathrm{kg}^{-1} \cdot \mathrm{min}^{-1}$ within $10 \mathrm{~min}$ and remained almost 2.5 -fold greater $(p<0.01)$ than those observed in control experiments despite the persistent hypoglycemia $(419 \pm 80$ versus $170 \pm 32 \mu \mathrm{U} \cdot \mathrm{kg}^{-1} \cdot \mathrm{min}^{-1}, \quad p<0.01$ ). Plasma cortisol, adrenaline and growth hormone increased to values significantly greater than those observed in control experiments (Fig.2). In contrast, at no time were plasma glucagon concentrations significantly different from those observed in control experiments despite the persistent hypoglycaemia. 


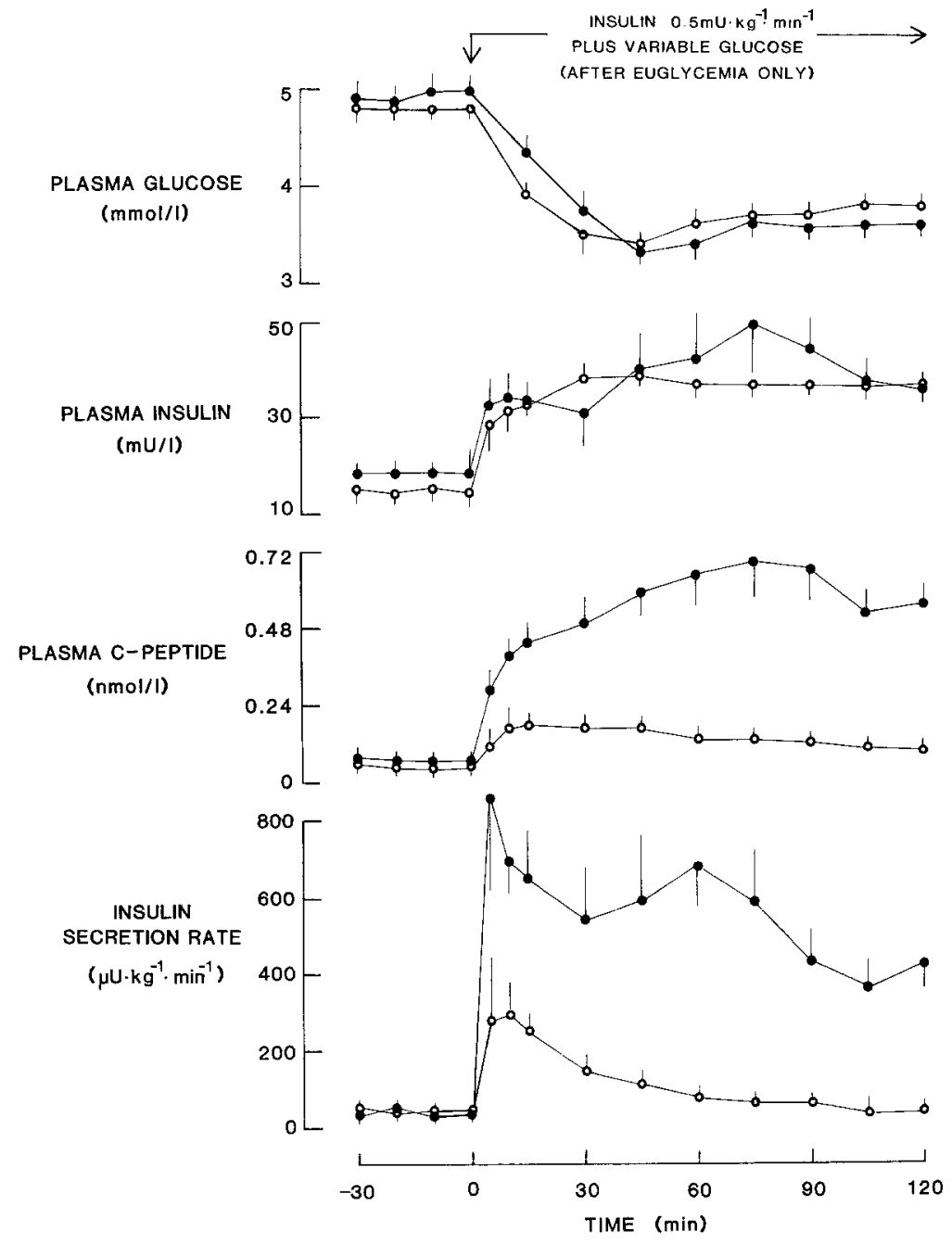

Fig. 3. Plasma glucose, insulin, and C-peptide concentrations and insulin secretion rates in normal volunteers during hypoglycaemia following cessation of somatostatin and replacement hormone infusions after 12-h euglycaemic $(O-O, n=6)$ and hyperglycaemic ( $-n=7$ ) clamps after the plasma glucose was clamped at comparable hypoglycaemic levels as was observed after the hyperglycaemic clamp (mean \pm SEM). The $\downarrow$ indicates the time at which the somatostatin and replacement hormone infusions were stopped
Islet $A$ - and B-cell responses during hypoglycaemia after prolonged hyperglycaemia and prolonged euglycaemia

To assess further the appropriateness of islet A- and Bcell responses during hypoglycaemia after prolonged antecedent hyperglycaemia, plasma glucose (after 12-h euglycaemia) was clamped at hypoglycaemic levels comparable to those observed after prolonged hyperglycaemia by infusion of insulin and a varable amount of glucose. Plasma insulin during the insulin infusion increased to values comparable to those occurring spontaneously after prolonged hyperglycaemia (37 mU/l; Fig. 3).

After discontinuation of the somatostatin-hormone replacement infusions, the suppressed plasma C-peptide concentrations increased less than in the control experiments in which hypoglycaemia did not occur $(0.09 \pm 0.02$ versus $0.24 \pm 0.02 \mathrm{nmol} / 1, p<0.05)$ and were only about $15 \%$ of the values found after prolonged hyperglycaemia. Insulin secretion initially increased to rates $\left(292 \pm 80 \mathrm{mU} \cdot \mathrm{kg}^{-1} \cdot \mathrm{min}^{-1}\right)$ comparable to those observed in the control experiments but then decreased to rates $<25 \%$ of those observed in the control experiments $\left(36 \pm 10\right.$ versus $170 \pm 32 \mu \mathrm{U} \cdot \mathrm{kg}^{-1}$. $\left.\min ^{-1}, p<0.01\right)$ and were $<10 \%$ of those observed after prolonged hyperglycaemia.

Plasma glucagon concentrations initially decreased transiently to a similar extent as in both other experiments (Fig.4). However, they increased subsequently more than twofold above baseline to peak levels nearly twice as great as those observed during the comparable hypoglycaemia which developed after prolonged hyperglycaemia $(50 \pm 7$ versus $31 \pm 4 \mathrm{pmol} / 1, p<0.01)$. Plasma adrenaline, growth hormone, and cortisol concentrations were not significantly different from those observed during comparable hypoglycaemia after prolonged hyperglycaemia.

\section{Discussion}

In the present studies, endogenous secretion of insulin, glucagon and growth hormone were suppressed by an infusion of somatostatin accompanied by replacement infusions of these hormones during $12 \mathrm{~h}$ of hyperglycaemia and $12 \mathrm{~h}$ of euglycaemia. Following euglycaemia, cessation of these infusions did not appreciably alter plasma glucose, insulin, glucagon, adrenaline and 

I- INSULIN O. $5 \mathrm{mu} \cdot \mathrm{kg}^{-1} \mathrm{mIn}^{-1}$ (AFTER EUGLYCEMIA ONLY)

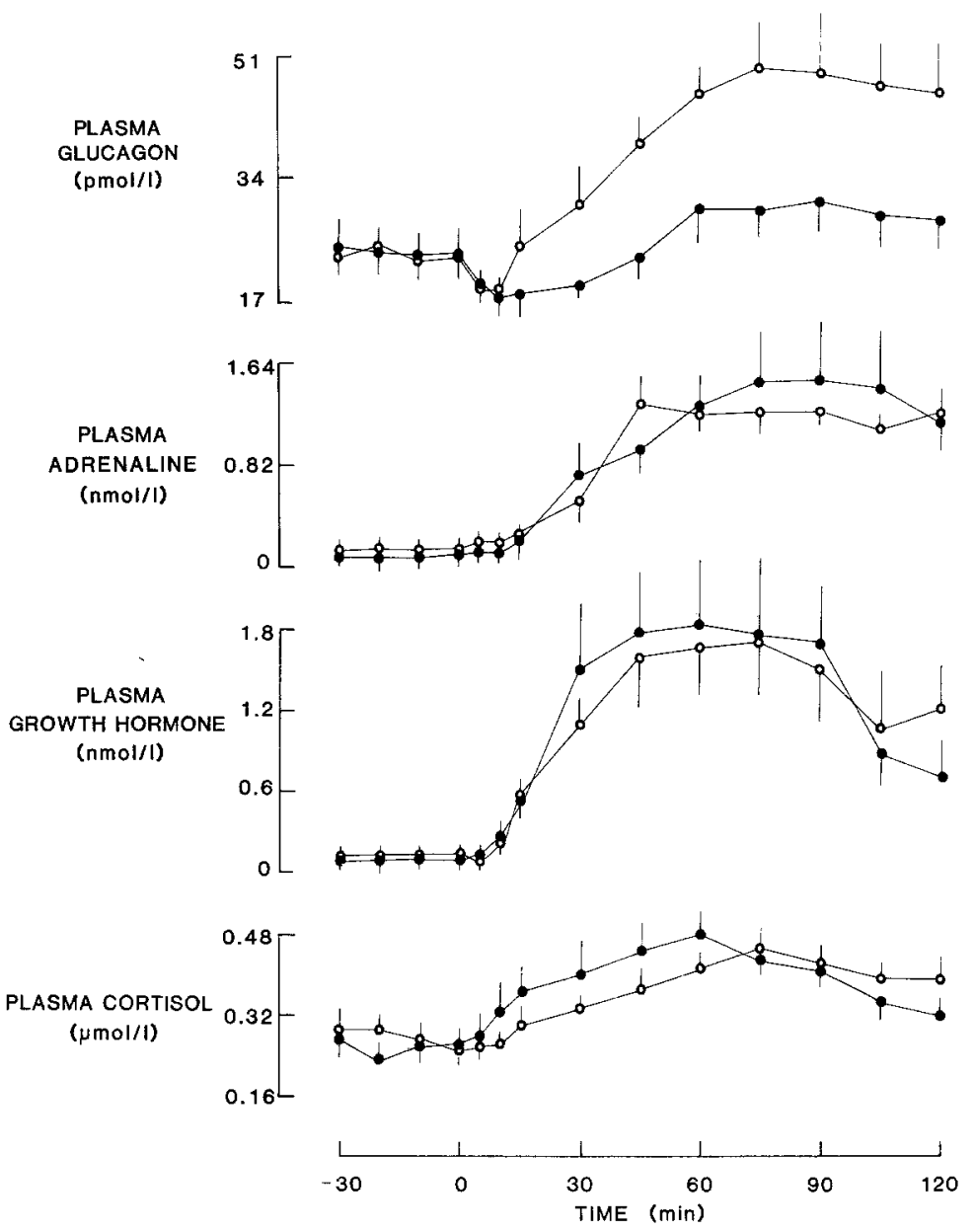

Fig.4. Plasma glucagon, adrenaline, growth hormone, and cortisol concentrations in normal volunteers during hypoglycaemia following cessation of somatostatin and replacement hormone infusions after 12 -h euglycaemic $(\mathrm{O}-\mathrm{O}, n=6)$ and hyperglycaemic $(\bullet, n=7)$ clamp after the plasma glucose was clamped at comparable hypoglycaemic levels as was observed after the hyperglycaemic clamp (mean \pm SEM). The $\downarrow$ indicates the time at which the somatostatin and replacement hormone infusions were stopped cortisol concentrations. Previously suppressed plasma C-peptide levels and rates of insulin secretion increased to normal values, and there was a transient rebound increase in plasma growth hormone. In contrast, when these infusions were stopped following $12 \mathrm{~h}$ of hyperglycaemia, plasma glucose concentrations decreased to nearly $3 \mathrm{mmol} / \mathrm{l}$, and there were sustained increases in plasma insulin, plasma C-peptide and rates of insulin secretion which were inappropriate for the concomitant hypoglycaemia; moreover there was a lack of an appropriate increase in plasma glucagon.

The initial increase in insulin secretion could be partly explained as a consequence of prolonged stimulation of insulin synthesis release by the antecedent hyperglycaemia $[23,24]$, which may have resulted in accumulation of insulin within B cells during infusion of somatostatin, an inhibitor of insulin secretion. Support for this is the observation of an initial transient increase in plasma growth hormone which, in contrast to that of insulin, was not sustained. However since hypoglycemia normally suppresses insulin secretion [25-27], once the plasma glucose concentration decreased to $3 \mathrm{mmol} / \mathrm{l}$ in the present studies, insulin secretion should have decreased to subnormal values, as was the case when comparable hypoglycaemia was induced after 12-h euglycaemia. The fact that increased insulin secretion peristed for at least $2 \mathrm{~h}$ in the presence of hypoglycaemia after antecedent hyperglycaemia, but not after antecedent euglycaemia, therefore suggests that the hyperglycaemia had altered impaired pancreatic B-cell sensitivity to glucose; i. e. the B cell had become resistant to the suppressive effect of decreased plasma glucose concentration.

Our data are consistent with a similar conclusion regarding pancreatic A-cell sensitivity to glucose. After prolonged hyperglycaemia, plasma glucagon concentrations did not increase above values observed in the control experiments despite a decrement in plasma glucose which has been shown otherwise to stimulate secretion of glucagon in normal man [28-30]. In contrast appropriate increases in the circulating levels of other counter-regulatory hormones were observed. It is likely, therefore, that the increases in plasma adrenaline were predominantly responsible for preventing plasma glucose from decreasing even further in the presence of in- 
creased insulin secretion and lack of an increase in glucagon secretion [31].

It might be argued that the augmented insulin secretion observed after $12 \mathrm{~h}$ hyperglycaemia may have prevented an appropriate plasma glucagon response to hypoglycaemia. This seems unlikely, because although plasma glucagon responses were absent during the spontaneous hypoglycaemia observed following $12 \mathrm{~h}$ of hyperglacaemia, plasma glucagon increased when hypoglycaemia was induced by an exogenous insulin infusion which resulted in comparable systemic circulating insulin levels. Moreover it has recently been shown that islet B-cell activity is probably not involved in negative modulation of islet A-cell responses to hypoglacaemia in man [32]. In the latter study plasma insulin concentrations greater than $130 \mathrm{mU} / 1$ induced by infusion of exogenous insulin did not prevent a two- to threefold increase in plasma glucagon in normal subjects during hypoglycaemia comparable to that observed in our study. The fact that plasma glucagon did not increase in the present study thus provides evidence that the prolonged antecedent hyperglycaemia had altered A-cell function.

The failure of a decrement in plasma glucose to suppress insulin secretion and to stimulate glucagon secretion following a period of sustained hyperglycaemia in the present study suggests that prolonged hyperglycaemia can impair both pancreatic A- and B-cell recognition of glucose and is compatible with the concept that prolonged hyperglycaemia may "down-regulate" the putative membrane or intracellular glucoreceptor mechanism of islet $A$ and $B$ cells. If this interpretation is correct, our results indicate that the abnormal islet Aand B-cell responses to glucose in diabetes mellitus may, at least in part, be a result of chronic hyperglycaemia and may not completely represent an intrinsic defect. Furthermore our results suggest a unifying explanation for the improvement an islet A- and B-cell function observed in patients with diabetes mellitus following restoration of near normoglycaemia by diverse modes of treatment [diet [33, 34], sulphonylureas [33], or insulin [35-38]]; namely, the reversal of a hyperglycaemia-induced A- and B-cell insensitivity to glucose.

An alternative interpretation of our data is that the antecedent hyperglycaemia had sensitized islet A and B cells to glucose and that this was responsible for the excessive insulin secretion and impaired glucagon release during subsequent hypoglycaemia. We prefer the former interpretation since it provides a possible explanation for amelioration of A- and B-cell function after improved glycaemic control though, acknowledge that further studies are needed to decide between these interpretations.

Acknowledgments. The excellent help of R. Westland, L. Hall, R. Rizza, W. Blanchard, J. King, T.Lund, K. Greene, and the staff of the General Clinic Research Unit, and the superb editorial assistance of $P$. Voelker are gratefully acknowledged. The work was supported in part by grants from the USPHS (AM-20411, RR-00585, AM-20579,
RR-00036) and from the Mayo Foundation. We thank the Novo Research Institute (Copenhagen, Denmark) for their provision of C-peptide kits.

\section{References}

1. Kipnis D (1969) Insulin secretion in diabetes mellitus. Ann Int Med 69: 981-901

2. Gerich J, Langlois M, Noacco D, Karam J, Forsham P(1973) Lack of glucagon response to hypoglycaemia in diabetes: evidence for an intrinsic pancreatic alpha-cell defect. Science 182: 171-173

3. Varsano-Aharon N, Echemedia E, Yalow R, Berson S (1970) Early insulin responses to glucose and tolbutamide in maturity-onset diabetes. Metabolism 19: 409-417

4. Robertson R, Porte D (1973) The glucose receptor: A defective mechanism in diabetes mellitus distinct from the beta adrenergic receptor. J Clin Invest 52: 87-876

5. Deckert T, Lauridsen U, Madsen S, Morgensen P (1972) Insulin response to glucose, tolbutamide, secretin, and isoprenaline in maturity onset diabetes mellitus. Dan Med Bull 19: 222-226 .

6. Turner R, Schneelock B, Nabarro J (1971) Biphasic insulin secretory response to intravenous xylitol and glucose in normal, diabetic and obese subjects. J Clin Endocrinol Metab 33: 301-307

7. Palmer J, Benson J, Walter R, Ensinck J (1976) Arginine-stimulated acute phase of insulin and glucagon secretion in diabetic subjects. J Clin Invest 58: 565-570

8. Unger R, Aguilar-Parada E, Muller W, Eisentraut A (1970) Studies of pancreatic alpha cell function in normal and diabetic subjects. $\mathbf{J}$ Clin Invest 49: 837-848

9. Gerich J, Langlois M, Noacco C, Lorenzi M, Karam J, Forsham P (1976) Comparison of suppressive effects of hyperglycaemia and elevation of plasma free fatty acid levels on glucagon secretion in normal and insulin-dependent subjects: Evidence for selective alpha cell sensitivity to glucose in diabetes mellitus. J Clin Invest 58: $320-325$

10. Unger R, Madison L, Muller W (1972) Abnormal alpha cell function in diabetes: Response to insulin. Diabetes 21: 301-309

11. Cerasi R, Luft R, Efendic S (1972) Decreased sensitivity of the pancreatic beta cells to glucose in prediabetic and diabetic subjects: A glucose dose-response study. Diabetes 21:224-234

12. Niki A, Niki H (1975) Is diabetes a disorder of the glucoreceptor? Lancet 2: 658-659

13. Kahn C, Baird K, Flier J, Grunfeld C, Harmon J, Harrison L, Karlsson F, Kasuga M, King G, Lang U, Podskalny J, Obberghen E (1981) Insulin receptors, insulin antibodies and the mechanism of insulin action. Rec Prog Horm Res 37: 477-538

14. Verdonk C, Rizza R, Westland R, Service J, Nelson R, Gerich J (1980) Glucose clamping using the biostator. Horm Metab Res 12: 133-136

15. Faber O, Binder C, Markussen J, Heding L, Naithani V, Kuzuya $H$, Blix P, Horwitz D, Rubenstein A (1978) Characterization of seven C-peptide antisera. Diabetes 27 (Suppl 1): 170-177

16. Herbert V, Lau K, Gottlieb C, Bleicher S (1965) Coated charcoal immunoassay of insulin. J Clin Endocrinol Metab 25: 1375-1384

17. Faloona G, Unger R (1974) Glucagon. In: Jaffe B, Behrman H (eds) Methods of hormone radioimmunoassay. Academic Press, New York, pp 317-330

18. Peake G (1974) Growth hormone. In: Jaffe B, Behrman H (eds) Methods of hormone radioimmunoassay. Academic Press, New York, pp 103-121

19. Murphy B (1967) Some studies of the protein-binding steroids and their application to the routine micro- and ultramicromeasurement of various steroids in body fluids by competitive proteinbinding radioassay. J Clin Endocrinol Metab 27: 973-990

20. Cryer P (1976) Isotope-derivative measurements of plasma norepinephrine and epinephrine in man. Diabetes 25: 1071-1082

21. Bolli G, Gottesman I, Cryer P, Gerich J (1984) Glucose counterregulation during prolonged hypoglycaemia in normal man. Am J Physiol 247: E206-214 
22. Eaton R, Allen R, Schade D, Erickson K, Standefer J (1980) Prehepatic insulin production in man: kinetic analysis using peripheral connecting peptide behavior. J Clin Endocrinol Metab 51: $520-528$

23. Andersson A, Westman J, Hellerström C (1974) Effects of glucose on the ultrastructure and insulin biosynthesis of isolated mouse pancreatic islets maintained in tissue culture. Diabetologia 10: 743-753

24. Porte D, Pupo A (1969) Insulin responses to glucose: evidence for a two pool system in man. J Clin Invest 48:2309-2319

25. Goldfine I, Cerasi E, Luft R (1972) Glucagon stimulation of insulin release in man: inhibition during hypoglycaemia. J Clin Endocrinol Metab 35: 312-315

26. Efendic S, Cerasi E, Luft R (1971) Role of glucose in arginine-induced insulin release in man. Metabolism 20:568-578

27. Horwitz D, Rubenstein A, Reynolds C, Molnar G, Yanaihara N (1975) Prolonged suppression of insulin release by insulin-induced hypoglyaemia: demonstration by C-peptide assay. Horm Metab Res 7: 449-452

28. Santeusanio F, Bolli G, Massi-Benedetti M, DeFeo P, Angeletti G, Compagnucci P, Calabrese G, Brunetti P (1981) Counterregulatory hormones during moderate, insulin-induced, blood glucose decrements in man. J Clin Endocrinol Metab 52: 477-482

29. Santiago J, Clarke W, Shah S, Cryer P (1980) Epinephrine, norepinephrine, glucagon and growth hormone release in association with physiological decrements in the plasma glucose concentration in normal and diabetic man. $\mathrm{J}$ Clin Endocrinol Metab 51: $877-883$

30. Sacca L, Sherwin R, Hendler R, Felig P (1979) Influence of continuous physiologic hyperinsulinemia on glucose kinetics and counterregulatory hormones in normal and diabetic man. J Clin Invest 63: 849-857

31. Rizza R, Cryer P, Gerich J (1979) Role of glucagon, catecholamines, and growth hormone in human glucose counterregulation: effects of somatostatin and combined $\alpha$ and $\beta$ adrenergic blockade on plasma glucose recovery and glucose flux rates following insulin-induced hypoglycaemia. J Clin Invest 64: 62-71

32. Bolli G, Tsalikian E, Haymond M, Cryer P, Gerich J (1984). Defective glucose counterregulation after subcutaneous insulin in non- insulin-dependent diabetes mellitus. Paradoxical suppression of glucose utilization and lack of compensatory increase in glucose production, roles of insulin resistance, abnormal neuroendocrine responses, and islet paracrine interactions. J Clin Invest 73: 1532-1541

33. Kosaka K, Kuzuya T, Akanuma Y, Hagura R (1980) Increase in insulin response after treatment of overt maturity-onset diabetes is independent of the mode of treatment. Diabetologia 18: 23-28

34. Savage $P$, Bennion L, Flock E, Nagulesparan M, Mott D, Roth J, Unger R, Bennett $P$ (1979) Diet-induced improvement of abnormalities in insulin and glucagon secretion and in insulin receptor binding in diabetes mellitus. J Clin Endocrinol Metab. 48: 999-1007

35. Berger D, Floyd J, Pek S (1981) The effect of treatment of Type 2 (insulin-independent) diabetes mellitus on plasma concentrations of pancreatic polypeptide and glucagon. Diabetologia 21: $120-125$

36. Raskin P, Pietri A, Unger R (1979) Changes in glucagon levels after four to five weeks of glucoregulation by portable insulin infusion pumps. Diabetes 28: 1033-1035

37. Vague $P$, Moulin J (1982) The defective glucose sensitivity of the B-cell in noninsulin dependent diabetes: improvement after twenty-four hours of normoglycaemia. Metabolism 31: 139-142

38. Schmeltz R, Wendorff H, Field J (1978) Effect of control of blood glucose on plasma insulin responses to various stimuli in secondary failures to oral hypoglycaemic agents and in newly diagnosed maturity onset, ketosis-resistant diabetics. J Clin Endocrinol Metab $46: 519-527$

Received: 26 March 1984

and in revised form: 8 November 1984

Dr. John E. Gerich

Endocrine Research Unit

Mayo Clinic

Rochester

MN 55905

USA 